\title{
Determination of Antigenic Proteins of Housedust Mites in 90 Dogs Suffering from Atopic Dermatitis
}

\author{
Kohei YAMASHITA ${ }^{1)}$, Chiharu FUJIWARA ${ }^{1)}$, Ryouji AZUMA ${ }^{2)}$, Takeshi SAWAZAKI ${ }^{1)}$, Yoshiki NAKAO ${ }^{1)}$ and \\ Atsuhiko HASEGAWA ${ }^{3)}$ \\ ${ }^{1)}$ Pharmaceutical Research Laboratory, Hitachi Chemical Co., Ltd., 4-13-1 Higashi-cho, Hitachi-shi, Ibaraki 317-8555, ${ }^{2)}$ Azuma Animal \\ Hospital, Tokyo 202-0011 and ${ }^{3)}$ Department of Pathobiology, Nihon University School of Veterinary Medicine, Kanagawa 252-0813, \\ Japan
}

(Received 18 December 2001/Accepted 1 April 2002)

ABSTRACT. Housedust mites, Dermatophagoides pteronyssinus (D. pteronyssinus) and Dermatophagoides farinae (D. farinae), are the important causative agents of allergic diseases in human and animals. By using 165 dogs suffering from atopic dermatitis (AD), serum levels of immunogloblin E (IgE) antibody against 25 kinds of allergen including housedust mites were determined. Housedust mites were the most frequent allergen against which 90 of the 165 allergic dogs $(54.5 \%)$ by IMMUNODOT assay. With the further analysis of immunoblotting assay in the 90 dogs sensitized with housedust mites, antigenic proteins of housedust mites recognized by IgE antibodies were with the apparent molecular masses of 15, 76, 90, 98, and 170-kD. Among them, the 15-kD protein that might be ident ical to Group 2 antigens (Der f2, Der p2) was prominently observed (52/90). This study indicates that about a half of dogs with AD were sensitized to housedust mites, suggesting that Group 2 antigens of housedust mites may be a major allergen in canine AD.

KEY WORDS: allergen, atopic dermatitis, canine, housedust mite, IgE.

J. Vet. Med. Sci. 64(8): 673-676, 2002

In recent years, the number of patients with allergic diseases has been increasing in dogs as well as in humans $[2,5$, $7,10,20]$. Immunogloblin $\mathrm{E}$ ( $\mathrm{IgE}$ ) antibodies play an important role in the development of immediate hypersensitivity (type I allergic disease) [7, 10, 20]. Binding of multivalent allergens to specific $\operatorname{IgE}$ antibody on mast cells or basophils leads to the release of histamine and arachidonic acid metabolites. These substances act as inflammatory mediators inducing various symptoms of allergic diseases such as dermatitis, urticaria, asthma, rhinitis, and conjunctivitis. Housedust mites, Dermatophagoides pteronyssinus (D. pteronyssinus) and Dermatophagoides farinae (D. farinae), have been recognized as important environmental allergens in human allergic diseases [19]. The antigenic proteins of housedust mites have been determined with intra-dermal skin test (IDST) and immunochemical method. In fact, over 10 different allergens of housedust mites are identified and characterized with known cDNA and/or Nterminal amino acid sequence $[8,14,15,22]$. Group 1 and Group 2 antigens are the major allergen in human allergic diseases involved in the onset of type I hypersensitivity [8, $15,22]$. Also in dogs, housedust mites have been recognized as important allergens in the atopic dermatitis (AD) $[11,13,17]$, however little is known about the antigenic proteins in housedust mites. And also, it has been reported that Group 1 and Group 2 antigens were rather minor allergen in dogs [13]. Until recently, unlike to human, the involvement of $\mathrm{IgE}$ antibody and causative antigens has not been investigated in canine AD.

In the present study, we determined serum levels of IgE antibodies against housedust mites for 165 dogs suffering from $\mathrm{AD}$, and investigated the involvement of housedust mites in canine AD. Furthermore, the reactivity of house- dust mites-specific IgE antibodies was examined in the dogs sensitized to housedust mites with immunoblot assay and ELISA for the antigenic proteins in housedust mites.

\section{MATERIALS AND METHODS}

Antigens: Crude antigens; GS mites mix (mixture of $D$. pteronyssinu and D. farinae), was purchased from Greer Laboratory (Lenoir, NC, U.S.A.). Purified antigens; Der f 1 and Der f 2 were purchased from Asahi Beer (Tokyo, Japan), and Der p 1 and Der p 2 were kindly gifted from Dr. Sakaguchi of National Institution of Infectious Disease (Tokyo, Japan).

Dogs: 165 dogs suffering from AD were selected as the clinical cases, which visited or hospitalized at 74 facilities in Japan from April to August in 1996. The clinical diagnosis of AD was performed in accordance with Williemse's criteria [20]. Dogs associated with deep pustular pyoderma and seborrhic dermatitis were excluded from this study.

IMMUNODOT assay: Serum levels of IgE antibody against 25 kinds of allergens were determined with commercially available kits, IMMUNODOT (CMG/Heska Allergy Products, Fribourg, Switzerland) as previously described [3]. Briefly, serum samples were added to the nitrocellulose strips on which 5 allergens were dotted. After incubation, strips were incubated with a peroxidase-labeled mouse monoclonal anti-dog IgE antibody for $2 \mathrm{hr}$ at room temperature. The strips were then incubated with substrate solution (4-chlolo-1-naphtol $+\mathrm{H}_{2} \mathrm{O}_{2}$ ) for colorimetric detection. The color intensity of each dot was measured with a densitometer (FAG, Fribourg, Switzerland). If the optical density was higher than 0.02 , it was considered as positive.

SDS-PAGE and immunoblotting: Crude extracts of 
housedust mites were separated by SDS-PAGE according to the method of Laemmli [9] using a 5-20\% gradient gel (Atto, Tokyo, Japan) under reducing condition and transferred to nitrocellulose membrane (Millipore, Bedford, MA, U.S.A.). The membrane was incubated with 5\% BSA for 1 $\mathrm{hr}$ at room temperature and then incubated with the undiluted serum overnight at $4^{\circ} \mathrm{C}$. The membrane was further incubated with horseradish peroxidase (HRP)-conjugated mouse anti-dog IgE antibody (CMG/Heska Allergy Products, Fribourg, Switzerland) or HRP-conjugated mouse antiDer f2 (Asahi Beer, Tokyo, Japan) for $1 \mathrm{hr}$ at room temperature. After incubation, immunoreactive proteins on the membrane were visualized with a TMB Membrane Peroxidase Substrate System (KPL, MD, U.S.A.) according to the manufacturer's protocol.

Enzyme-linked immunosorbent assay (ELISA): Each well of a microtiter plate (MaxiSorp, Nunc, Denmark) was coated with $1 \mu \mathrm{g}$ of antigen in $0.1 \mathrm{M}$ carbonate-bicarbonate buffer $(\mathrm{pH}=9.6)$ overnight at $4^{\circ} \mathrm{C}$. After blocked with $5 \%$ BSA for $1 \mathrm{hr}$ at room temperature, serum samples at a dilution of 1:20 were added to the wells and incubated for $2 \mathrm{hr}$ at room temperature. The plates were then incubated with a peroxidase-conjugated mouse anti-canine IgE antibody (CMG/Heska Allergy Products, Fribourg, Switzerland) for $2 \mathrm{hr}$ at room temperature. Finally, TMB Membrane Peroxidase Substrate System (KPL, MD, U.S.A.) was added to the well for color development. After the enzyme reaction was stopped with $1 \mathrm{M} \mathrm{H}_{3} \mathrm{PO}_{4}$, the optical density was measured at $450 \mathrm{~nm}$ with a microplate reader (Tosoh, Tokyo, Japan). If the optical density was higher than "mean +3SD" of 10 reference sera, it was considered as positive.

\section{RESULTS}

Housedust mites-specific IgE antibody: By using 165 dogs suffering from AD, serum levels of immunogloblin $\mathrm{E}$ (IgE) antibody against 25 allergen including housedust mites were determined. Housedust mites were the most frequent allergen against 90 dogs sensitized $(54.5 \%)$, followed by storage mites $(18.6 \%)$, rye grass $(13.4 \%)$, cat flea $(12.5 \%)$ and Japanese cedar $(10.3 \%)$. The frequency of food and mould allergens was comparatively lower than that of indoor or outdoor allergens in this study.

Background factor of 90 dogs sensitized with housedust mites: We investigated the background factor (sex, onset age, season to develop symptoms, keeping place) of $90 \mathrm{dogs}$ sensitized with housedust mites. $34(37.8 \%)$ were male and $57(62.2 \%)$ were female. The onset age included $0-3$ years $(66.7 \%), 4-6$ years $(23.3 \%)$, and $7-9$ years $(10.0 \%)$. In the season to develop symptoms of $\mathrm{AD}$, whole year was the highest $(63.3 \%)$, followed by spring $(30.0 \%)$, summer $(22.2 \%)$, autumn $(8.9 \%)$, and winter $(1.1 \%)$. In the keeping place, $66(73.3 \%)$ were indoor and $15(16.7 \%)$ were outdoor.

Immunobloting assay for housedust mites: By using 90 dogs sensitized with housedust mites, we performed immunoblotting assay for crude housedust mites extract in order

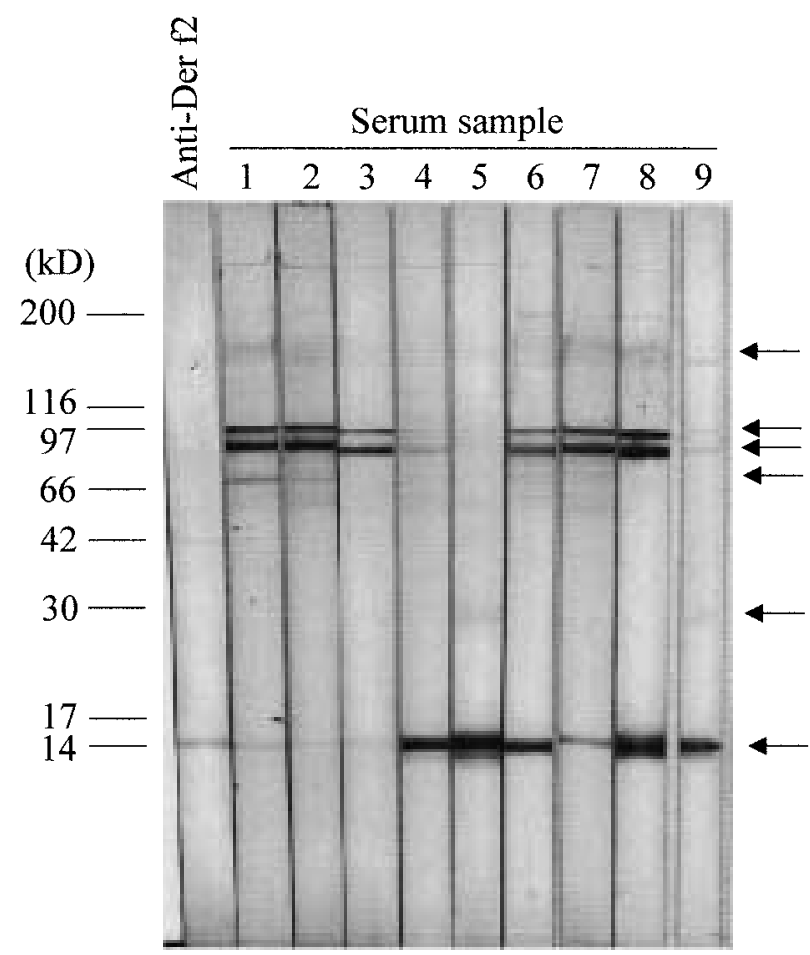

Fig. 1A. Immunobloting patterns showing the reactivity of $\operatorname{IgE}$ antibody to housedust mites in different dogs sensitized with them. The crude extracts of housedust mites were separated by SDS-PAGE and the separated proteins were transferred to nitrocellulose membrane. The membrane was incubated with serum and then reactive proteins were detected by HRP-labeled anti$\operatorname{dog} \operatorname{IgE}$ antibody. Arrows indicate the frequent proteins against which the patient's IgE antibody or HRP-labeled anti-Der f2 antibody reacts.

to investigate the antigenic proteins in it, that were recognized by patient's IgE antibody (Fig. 1). Figure 1A showed that the molecular mass of antigenic proteins recognized by IgE antibody was ranged from $15-\mathrm{kD}$ to $170 \mathrm{kD}$. In the experiments, the proteins with the apparent molecular masses of $15,26,76,90,98$, and $170-\mathrm{kD}$ were prominently observed, and the $15-\mathrm{kD}$ was the most dominant among them (Fig. 1B). Since the $15-\mathrm{kD}$ protein was also detected by using anti-Der $\mathrm{f} 2$ antibody (Fig. 1A), the apparent molecular masses of the $15-\mathrm{kD}$ might be identical to Group 2 antigen that is a major allergen of housedust mites in human allergic diseases.

ELISA assay for crude and purified antigens of housedust mites: To validate the IgE-reactivity to Group 2 antigens (Der $\mathrm{f} 2$ and Der p2), ELISA with purified Der f2 and Der p2 were performed in the 90 dogs sensitized with housedust mites. At the same time, we examined the IgE-reactivity to Group 1 antigens (Der f1 and Der p1), in order to compare the reactivity with Group 2 antigens. Table 1 indicated the number of dogs that showed the positive reactivity of $\mathrm{IgE}$ against each purified antigen. The number of dogs with IgE-reactivity against Der f1, Der p1, Der f2, and Der p2 


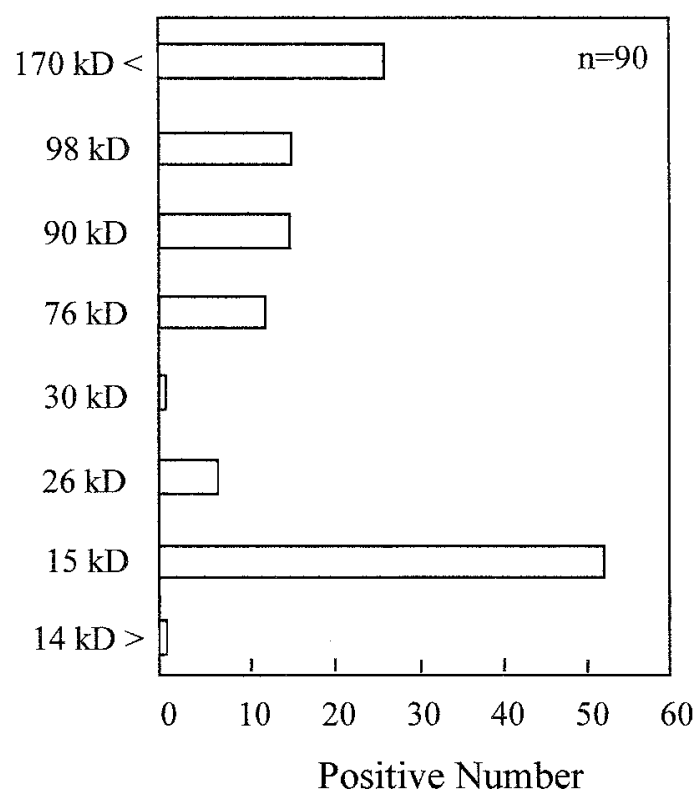

Fig. 1B. The number of cases in the $90 \mathrm{dogs}$ sensitized with housedust mites, reacted to each distinct protein detected by the immunoblotting assay.

was $40,7,67$, and 20, respectively. The frequency of Der $\mathrm{f} 2$ (74.4\%), Group 2 antigens of D. farinae mite, was comparably high. On the other hand, Der p2 $(22.2 \%)$, Group 2 antigens of $D$. pteronyssinus mite, were less frequent than Der f1 (44.4\%), Group 1 antigens of $D$. farinae mite.

\section{DISCUSSION}

Until recently, research in dog allergy has been impaired by the lack of a highly specific antibody that recognize dog IgE antibody. De Boer et al. have obtained highly specific and purified monoclonal mouse anti dog $\operatorname{IgE}$ antibody [1], and a few diagnostic tests based on the monoclonal antibody such as IMMUNODOT have been commercially available $[3,6]$. Such reagents would be used in the clinical diagnosis of canine allergic diseases.

Our clinical study on 165 dogs suffering from AD indicated that the prevalence of specific $\mathrm{IgE}$ antibody against housedust mites $(54.5 \%)$ was the highest in the 25 allergens examined. This result suggested that housedust mites might be important causative allergen in the canine $\mathrm{AD}$, as is the similar phenomena in human. In clinical allergy, it is important to identify the allergenic components in each allergen used for diagnostic test and/or immunotherapy. In case of human allergic diseases, housedust mites is considered to become a critical incident of asthma and rhinitis, and more than 10 kinds of allergenic proteins were known. In these proteins, Group 1 (26-kD) and Group 2 antigens (15-kD) were proved to have specific IgE-reaction in majority of human patients suffering from AD or asthma [14]. Our immunoblotting assay demonstrated that IgE-reactivity to
Table 1. The number of dogs sensitized with purified antigen in housedust mite (Der f1, Der f2, Der p1, Der p2)

\begin{tabular}{lcc}
\hline Species & Antigen & Positive number (rate) \\
\hline D. farinae & Der f1 (Group 1) & $40(44.4 \%)$ \\
& Der f2 (Group 2) & $67(74.4 \%)$ \\
D. pteronyssinus & Der p1 (Group 1) & $7(7.8 \%)$ \\
& Der p2 (Group 2) & $20(22.2 \%)$ \\
\hline
\end{tabular}

some kinds of distinct proteins with the molecular masses of $15,26,76,90,98$, and $170-\mathrm{kD}$ was prominently detected in dogs sensitized with housedust mites. Among them, 15-kD protein close to Group 2 antigens was the most dominant one $(52 / 90)$. On the other hand, $26-\mathrm{kD}$ protein close to Group 1 antigens was rather minor one (8/90). Therefore, the $15-\mathrm{kD}$ of antigenic component recognized by $57.8 \%$ of dogs sensitized with housedust mites might be considered as a major allergen in canine AD. The other four antigenic proteins with molecular masses of 76, 90, 98, and $170-\mathrm{kD}$ had frequencies below $30 \%$. Though the significance of these proteins of housedust mites in canine $\mathrm{AD}$ are not clear at present, high molecular weight proteins, 92, 98, 177-kD, were recently reported as one of the important allergens in the human athmatic patients $[4,18]$. They identified and characterized a $98-\mathrm{kD}$ allergen against which greater than $80 \%$ of patients allergic to housedust mites showed IgE reactivity. Nori et al. reported that $\mathrm{IgGd}$ antibody rather than $\mathrm{IgE}$ antibody might play an important role in canine atopic dermatitis, and that the $90-\mathrm{kD}$ proteins recognized by IgGd antibodies were one of the important antigens in housedust mites. They also reported that little IgE-response to Group 1 and Group 2 antigens were observed in the dogs suffering from $\mathrm{AD}$, and they were rather the different responses observed in human allergic diseases.

Then, we investigated the IgE-reactivity to purified mites antigens, Der f1, Der f2, Der p1, and Der p2, in order to validate the results shown in immunoblotting study. In our study, 67 of the 90 dogs $(74.4 \%)$ sensitized with housedust mites had strong IgE-reactivity to Der f2. In agreement with the immunoblotting study, Der f2 was dominant antigen among the four purified proteins. It should be noted that the IgE-reactivity to the each purified antigen from $D$. farinae mite, Der f1 and Der f2, was relatively higher than that of $D$. pteronyssin mite, Der $\mathrm{p} 1$ and Der $\mathrm{p} 2$. In the previous studies, it has been reported that the responses of intradermal skin test (IDST) as well as specific IgE-reation were much dominant for $D$. farinae compared with $D$. pteronyssin in dogs suffering from AD, nevertheless to the geographic distribution of $D$. farinae and D. pteronyssinus mites [12, 13, $16,21,22]$. Our studies using purified antigen confirmed the results from these previous reports, because $D$. pteronyssinu mite is rather predominant species compared with $D$. farinae mite in Japan [16, 22].

In summary, these studies show the importance of housedust mites in canine $\mathrm{AD}$, and suggest that the Group 2 antigens, especially Der f2 of $D$. farinae mite, are one of the 
major allergen in AD dogs allergic to housedust mites.

\section{REFERENCES}

1. DeBoer, D.J., Ewing, K.M. and Schultz, K.T. 1993. Production and characterization of mouse monoclonal antibodies directed against canine IgE and IgG. Vet. Immunol. Immunopathol. 37: 183-199.

2. de Weck, A.L. 1995. What can we learn from the allergic zoo? Int. Arch. Allergy Immunol. 107: 13-18.

3. de Weck, A.L., Derer, M., Mayer, P., Stumper, B., Schoni, B., Hammerling, R., Kristensen, F., Itaya, H., Yamashita, K. and Hasegawa, A. 1998. Review and perspectives of diagnostics of canine allergies: a new serologic method for determination of allergen specific IgE with strip tests. Praktische Tierarzt 79: 623 (in German).

4. Fujikawa, A., Uchida, K., Yanagidani, A., Kawamoto, S., Aki, T., Shigeta, S., Wada, T., Suzuki, O., Jyo, T. and Ono, K. 1998. Altered antigenicity of M-177, a $177-\mathrm{kDa}$ allergen from the house dust mite Dermatophagoides farinae, in stored extract. Clin. Exp. Allergy 28: 1549-1558.

5. Halliwell, E.W. and Schwartzmann, R.M. 1971. Atopic disease in dog. Vet. Rec. 98: 209-214.

6. Hammerling, R. and de Weck, A.L. 1998. Comparison of two diagnostic tests for canine atopy using monoclonal anti-IgE antibodies. Vet. Dermatol. 9: 191-199.

7. Hasegawa, A., Ogata, M., Iwasaki, T., Sakoh, T., Kuyama, T., Yonekura, T., Hashiguchi, K. and Sakaguchi, M. 1996. Measurement of allergen-specific dog IgE antibody in atopic dogs. Jpn. Small Anim. Dermatol. 2: 37-45 (in Japanese).

8. Heymann, P.W., Chapman, M.D., Aalberse, R.C., Fox, J.W. and Platts-Mills, T.A.E. 1989. Antigenic and structural analysis of group II allergens (Der f II and Der PII) from house dust mites (Dermatophagoides spp). J. Allergy. Clin. Immunol. 83: 1055-1067.

9. Laemmli, U.K. 1970. Cleavage of structural proteins during the assembly of the head of bacteriophage T4. Nature (Lond.) 227: 680-685.

10. Lina, T.M. and Halliwell, E.W. 1998. Allergen-specific IgE and $\mathrm{IgGd}$ antibodies in atopic and normal dogs. Vet. Immunol. Immunopathol. 66: 203-223.

11. Masuda, K., Sakaguchi, M., Fujiwara, S., Kurata, K., Yamashita, K., Odagiri, T., Nakao, Y., Matsuki, N., Ono, K., Watari, T., Hasegawa, A. and Tsujimoto, H. 2000. Positive reactions to common allergens in 42 atopic dogs in Japan. Vet. Immunol.
Immunopathol. 73: 193-204.

12. Masuda, K., Tsujimoto, H., Fujiwara, S., Kurata, K., Hasegawa, A., Yasueda, H., Yamashita, K., DeBoer, D.J., de Weck, A.L. and Sakaguchi, M. 1999. IgE sensitivity and cross-reactivity to crude and purified mite allergens (Der f1, Der f2, Der p1, Der p2) in atopic dogs sensitive to Dermatophagoides mite allergens. Vet. Immunol. Immunopathol. 72: 303-313.

13. Noli, C., Bernadina, W.E. and Willemse, T. 1996. The significance of reactions to purified fractions of Dermatophagoides pteronyssinus and Dermatophagoides farinae in canine atopic dermatitis. Vet. Immunol. Immunopathol. 52: 147-157.

14. Platts-Mills, T.A.E., Vervloet, D., Thomas, W.R., Alberse, R.C. and Chapman, M.D. 1997. Indoor allergens and asthma: report of third international workshop. J. Allergy Clin. Immunol. 100: 1-24.

15. Platts-Mills, T.A.E. and Solomon, W.R. 1993. Aerobiology and inherent allergens. pp. 469-528. In: (Middleton, E.J. et al. Allergy: Principles and Practice. eds.), C.V. Mosby, St. Louis.

16. Sakaguchi, M., Inouye, S., Yasueda, H. and Shida, T. 1992. Concentration of airborne mite allergens Der I and Der II during sleep. Allergy 47: 55-57.

17. Scott, D.W., Miller, W.H. and Griffin, C.E. 1995. Immunologic skin diseases. pp. 506-511. In: Small Animal Dermatology, 5th ed. Philadelphia: W. B. Saunders.

18. Tsai, L.C., Chao, P.L., Shen, H.D., Tang, R.B., Chang, T.C., Chang, Z.N., Hung, M.W., Lee, B.L. and Chua, K.Y. 1998. Isolation and characterization of a novel 98-kd Dermatophagoides farinae mite allergen. J. Allergy Clin. Immunol. 102: 295-303.

19. Voorhorst, R. and Van Krieken, H. 1973. Atopic skin test reevaluated. Variability in results of skin tests done in octuplicate. Ann. Allergy. 31: 499-508.

20. Willemse, T. 1986. Atopic skin disease: a review and a reconsideration of diagnostic criteria. J. Small Anim. Pract. 27: 771778 .

21. Willemse, T. 1987. Atopic dermatitis. pp. 57-77. In: Contemporary Issue in Small Animal Practice. Dermatology (Nesbitt, G.H. ed.).

22. Yasueda, H., Mita, H., Yui, Y. and Shida, T. 1989. Comparative analysis of physicochemical and immunochemical properties of two major allergens from Dermatophagoides pteronyssinus and the corresponding allergens from Dermatophagoides farinae. Int. Arch. Allergy Appl. Immunol. 88 : 402-407. 